\title{
First report of the mussel Mytella strigata (Hanley, 1843) in the Venezuelan Caribbean from an invasion in a shrimp farm
}

\author{
César Lodeiros $^{1,2}\left(\mathbb{D}\right.$, Dailos Hernández-Reyes ${ }^{3}\left(\mathbb{D}\right.$, José Miguel Salazar ${ }^{4}(\mathbb{D}$ \\ Manuel Rey-Méndez ${ }^{5}$ \& Nieves González-Henríquez ${ }^{3}$ \\ ${ }^{1}$ Grupo de Investigación en Biología y Cultivo de Moluscos, Escuela de Acuicultura y Pesquería \\ Facultad de Ciencias Veterinarias, Universidad Técnica de Manabí, Bahía de Caráquez, Ecuador \\ ${ }^{2}$ Instituto Oceanográfico de Venezuela, Universidad de Oriente, Cumaná, Venezuela \\ ${ }^{3}$ Laboratorio BioMol, Departamento de Biología, Facultad de Ciencias del Mar \\ Universidad de Las Palmas de Gran Canaria, España \\ ${ }^{4}$ Consultoría y Servicios Múltiples de Acuicultura, Cumaná, Venezuela \\ ${ }^{5}$ Laboratorio de Sistemática Molecular e Instituto de Acuicultura, CIBUS, Campus Vida \\ Universidad de Santiago de Compostela, Santiago de Compostela, España \\ Corresponding author: César Lodeiros (cesarlodeirosseijo@yahoo.es)
}

\begin{abstract}
Individuals of mussels were collected in ponds from a commercial shrimp farm in the Unare region, Anzoátegui State, Venezuela. Identification was carried out using dichotomous keys and corroborated via analysis of similarities between the sequences of partial mitochondrial DNA of the cytochrome oxidase gene and Mytella strigata (Hanley, 1843) reported in GenBank with 99-100\% similarity. Morphological analyses further supported the identification of the specimen. The first report of $M$. strigata in the Venezuelan Caribbean coast suggests that it could be a transplanted species. Possible negative effects of $M$. strigata on commercial shrimp production systems are discussed.
\end{abstract}

Keywords: Mytella strigata; bivalve mollusks; Penaeus vannamei; shrimp aquaculture; parasitic vector; COI; GenBank

In aquatic ecosystems, bivalve mollusks are among the most invasive groups. They can cause environmental disturbances due mainly to their filtering ability, which could produce quantitative and qualitative changes in the plankton, causing an imbalance in the food chain. Bivalves produce feces and pseudofeces that can alter the biogeochemical cycles, and shells can change the substrate's physical properties in the ponds (Strayer 1999, Ruesink et al. 2005). Mussels have caused important invasions in aquatic ecosystems. For example, the golden mussel Limnoperna fortune or the false mussels like Mytilopsis spp. and Dreissena spp. have been reported as responsible for invasions in aquatic systems producing large ecological and economic impacts (Mackie \& Claudi 2010, Spinuzzi et al. 2013, Boltovskoy et al. 2015), including shrimp farms where a reduction in production performance was observed (Farías-Sánchez et al. 2006, Aldridge et al. 2008, Lodeiros et al. 2019).

This study resulted from the observation of low performance in shrimp (Penaeus vannamei) production in cultivation ponds located in the Unare region, Anzoátegui State, at the central coast of Venezuela $\left(10^{\circ} 03^{\prime} 05^{\prime \prime} \mathrm{N}, 65^{\circ} 11^{\prime} 32^{\prime \prime} \mathrm{W}\right)$, which was associated with a large invasion of mussels. The farms encompassed a pond area of approximately 430 ha with a semiintensive farming system (16-18 ind $\mathrm{m}^{-2}$ ) and productions of $1600-1800 \mathrm{~kg} \mathrm{ha}^{-1}$ per cycle, in 2.3 crop cycles per year. Mangroves in the coastal zone characterize the area and continental vegetation inland, mainly tropical dry to a semi-arid forest. 
A visual inspection of the ponds and water channels was carried out, mainly detailing the water inlets and outlets and their slopes. In several ponds, lots of organisms of the invasive mussel of several sizes were manually collected.

According to Coan \& Valentich (2012) and Mediodia et al. (2017), their morphological characteristics taxonomically identified mussels. Tissues samples of these organisms (15 individuals) were preserved in $96 \%$ ethanol and transported to the Laboratory of Molecular Biodiversity of the University of Las Palmas de Gran Canaria (BioMol) for extraction, amplification, and sequencing of DNA. The "EZNA Mollusc Kit" of Omega Bio-Tek was used for DNA extraction, following the supplier's instructions. PCR obtained the COI gene fragments with the primers LCO1490/HCO2198 (Folmer et al. 1994). The PCR products were purified with ExoSAP-It kit (Affymetrix), and the sequencing reaction was carried out using the BigDye kit v3.1 and X terminator (Thermo Fisher Scientific). The sequence analysis was conducted with the ABI 3500 equipment (Thermo Fisher Scientific).

The nucleotide sequences obtained from the COI gene were aligned using the software Geneious using the ClustalW2 algorithm. The trimmed and aligned sequences were compared with those available in the GenBank (ftp://ftp.ncbi.nlm.nih.gov/genbank/), using the online software Nucleotide Blast (http: //blast.ncbi. nlm.nih.gov/Blast.cgi).

A large incidence of mussels was observed, particularly in the channels, fixed to different solid substrates (stones, wood, meshes, rubbers) (Fig. 1a). Equally, dense aggregations on muddy substrates were observed (Fig. 1b), pointing toward the high adaptability of the mussel to the prevailing substrate conditions of the ponds.

Mussel aggregations were also observed fixed to the concrete substrates and wooden boards used in the shrimp culture management (Figs. 2a-b). In the dry ponds, aggregations of mussels were also observed, particularly attached to concrete structures located at the inlets and outlets water drainages of the ponds and in the water floods towards the drainage channel, where the mussels were observed on larger hard substrates, including the shells of other bivalves (Fig. 2c). The invasive ability of this mussel was evidenced by the high incidence of juveniles attached to the nets used to limit the entry of organisms into the pond that was completely clogged within few days (Fig. 2d).

The mussel maximum size found was $76 \mathrm{~mm}$ in its anterior-posterior axis. The shells were symmetrical, joined by a long hinge in the dorsal part, elongatetrapezoidal shape, with a straight ventral edge in juveniles, becoming concave in upper sizes predominantly brownish to the black exterior color. However, some individuals showed a greenish color (Fig. 3). A characteristic and visible sculpture of fine commarginal ribs or semicircular rings was evident. Internally, the shell was colored in black or purple dark metallic, showing two muscle scars, the large posterior adductor muscle scar and the greatly reduced anterior adductor muscle. In the anteroventral margin, the shell has two small teeth. The internal and external shell characteristics were comparable to those of Mytella charruana (d'Orbigny, 1842) descriptions in Coan \& Valentich (2012) and Mediodia et al. (2017). Recent studies have shown that $M$. charruana, as M. falcata, are junior synonyms of $M$. strigata (Lim et al. 2018), and the name Mytella strigata (Hanley, 1843) is the correct scientific name today referred to in the World Register of Marine Species (MolluscaBase 2021).

The internal morphology regarding the position of the organs and the color of the tissues coincided with M. strigata in the description of Mediodia et al. (2017), which are characteristics of the family Mytilidae (Gosling 2003).

Comparing the 15 partial sequences of the COI gene, with an average of $680 \mathrm{bp}$, using the BLAST function with those deposited in the NCBI database, provided between 99-100\% similarity with Mytella strigata (Hanley, 1843), coinciding with the morphological identification.

The type locality of $M$. strigata is Rio de Janeiro in Brazil. Its original distribution range corresponds to the Atlantic coast of South America from the Gulf of Paria, Venezuela, to Argentina (Soot-Ryen 1955, Darrigrán \& Lagreca 2005). However, the species has been geographical expanding and is characterized as neotropical with distribution in the Atlantic and Pacific oceans coasts, in the Gulf of California from the Magdalena Bay $\left(24.6^{\circ} \mathrm{N}\right)$ and the north of Guaymas, Sonora, Mexico $\left(27.9^{\circ} \mathrm{N}\right)$, to Cangas, Tumbes, Peru $\left(4^{\circ} \mathrm{S}\right)$, Galapagos Islands, Ecuador on the Pacific coast and in the Western Atlantic from Venezuela to Argentina (Rios 1994, Coan \& Valentich 2012). However, there have been no records of the species in exhaustive inventories of the Colombian-Venezuelan Caribbean malacofauna (Díaz \& Puyana 1994, Capelo \& Buitrago 1998, Lodeiros et al. 1999, Bitter \& Martínez 2001). Nor benthic community studies in various localities, until Gillis et al. (2009), Puyana et al. (2012), Quirós \& Arias (2013), and De la Hoz (2013) that show the presence of M. strigata in the Bay of Cartagena, Bay of Cispatá and Gulf of Salamanca, Colombia, considering the most northern record in South America. Consequently, the only report of Mytella charruana (= Mytella strigata) for Venezuela is from Soot-Ryen 

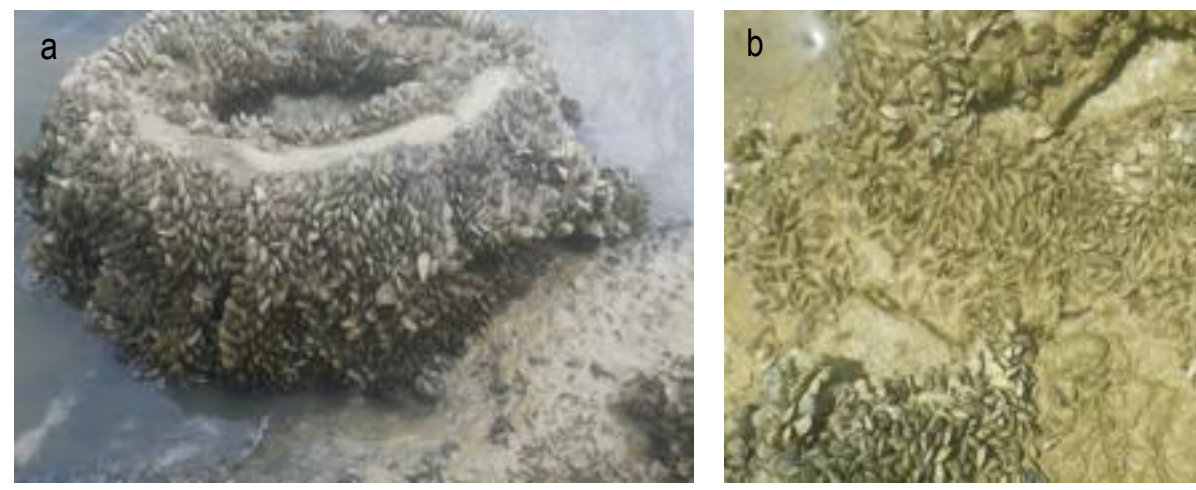

Figure 1. Mussels organisms fixed to rubber a) in muddy aggregations and, b) in the channels of the shrimp farm.
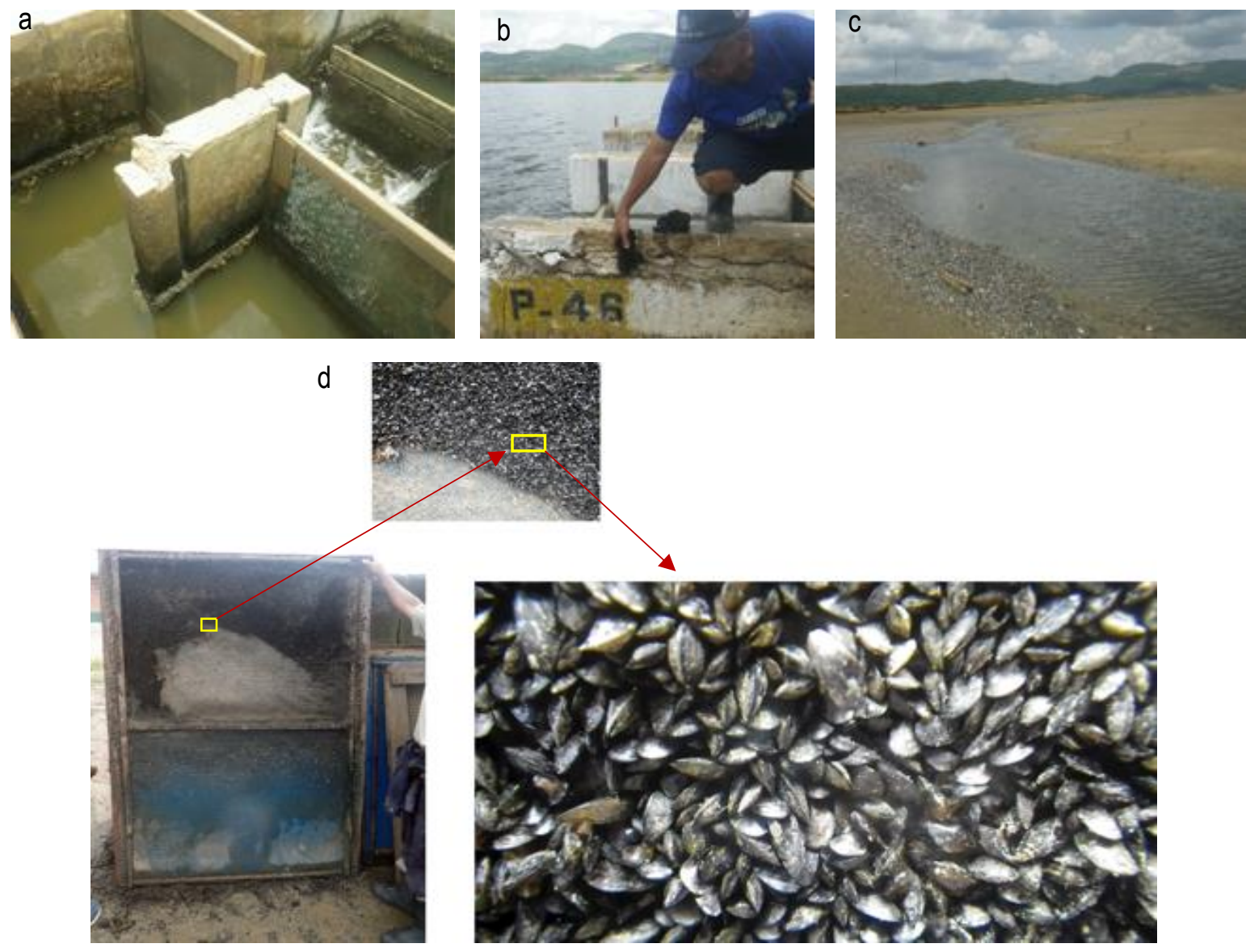

Figure 2. a-b) Mussels fixed to solid entry structures in the ponds, c) accumulation of shells in the floods formed in the ponds, and d) high incidence of small mussels in the meshes used to control the entry of organisms into the ponds of the shrimp farm.

(1955) for the Gulf of Paria, in the Guianan marine ecoregion, one of the two ecoregions to which the coasts of Venezuela belong (Spalding et al. 2007). Since there is no previous report published on this species for the coasts of the Venezuelan Caribbean (southwestern Caribbean ecoregion), this study corres- ponds to the first report of the species for the Venezuelan Caribbean.

Recent reports in the Colombian Caribbean (excluding the Venezuelan Caribbean), together with the reports distributed along the South American coast in the Atlantic from the Gulf of Paria to Argentina and in 

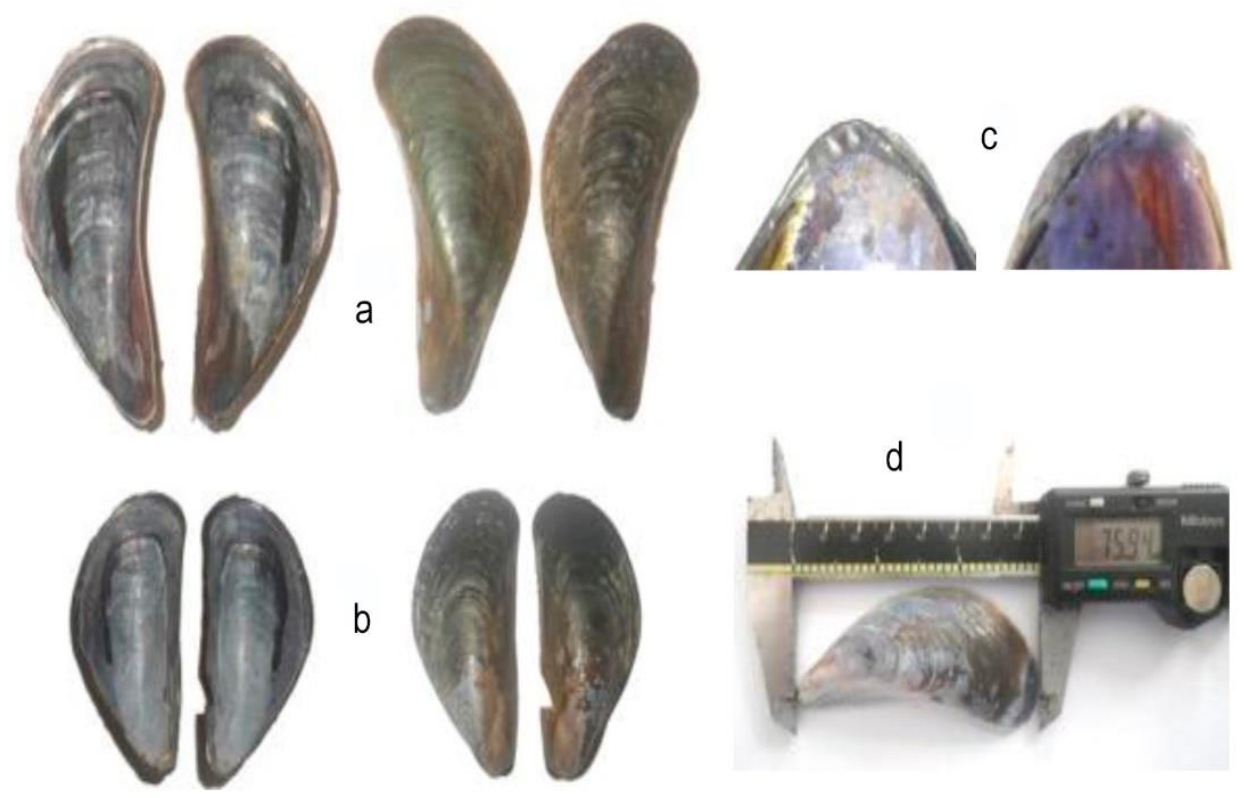

Figure 3. Interior and exterior shells of mussels collected in the shrimp farm. a) Advanced adults appreciating their curved shape in the ventral shell, b) juveniles with their straight shape, c) tooth detail, d) maximum length found.

various points of Mexico to Ecuador in the Pacific (Lim et al. 2018), suggest that M. strigata in the Venezuelan Caribbean is a transplanted species. The proximity of the study site to the Jose oil industrial complex in Anzoátegui State, where there is a high activity of oil tanker navigation, could be associated with mussel transplantation, either by ballast water from ships or reproduction and export of larvae from mussels in the hulls of ships.

Mytella strigata has also invaded the lagoon system in 2004 from the Indian River in Florida, USA. Since then, its proliferation as an invasive species on Florida, South Carolina, and Georgia coasts has become evident (Boudreaux \& Walters 2006, Gillis et al. 2009, Spinuzzi et al. 2013, Calazans et al. 2017). Recently, it has been considered an invasive species in India (Jayachandran et al. 2019) and Southeast Asia, principally the Philippines, Singapore, and Thailand (Rice et al. 2016, Vallejo et al. 2017, Lim et al. 2018, Sanpanich \& Wells 2019).

The introduced and transplanted species can pose an invasion risk. The fact that $M$. strigata is eurytherm, resistant to high-temperature ranges, with reproduction in small sizes (M. strigata can reach reproductive maturity at a length of $1.25 \mathrm{~cm}$, according to Stenyakina et al. 2010) and can adapt to various types of substrates (Darrigran \& Lagreca 2005, Boudreaux \& Walters 2006, Paredes \& Cardoso 2008, De la Hoz 2013) suggests that $M$. strigata is a generalist species with high dispersion capacity.
In Colombia, M. strigata has been reported as a high-risk species (Baptiste et al. 2010). In lagoons off the coast of Florida (USA), it can compete with native oysters and significantly alter the planktonic abundance, limiting the availability of food for other filtering species (Galimany et al. 2017). Similarly, Wells (2017) and Sanpanich \& Wells (2019) show that invasion by $M$. strigata could cause considerable damage to Perna viridis fisheries and cultivation and marine ecosystems in southeast Asia.

The invasion of $M$. strigata to shrimp farms has been associated with negative factors in the yield, considering it an undesirable organism (Farías-Sánchez 2006). Mussels aggregations can reduce the flow of water in passage channels or pipes, in the ponds can reduce phytoplankton and suspended organic matter, as well as oxygen concentration, and cause clarity in shrimp ponds (originating greater visualization by predatory birds), causing negative impacts on shrimp growth and survival. They can also generate a scenario of decreased alkalinity and hardness, particularly in low salinity waters producing effects on the shrimp exoskeleton formation, commonly known as a softshell, with very negative consequences for both growth and crop planning and poor quality for the processing and final sale of the shrimp (Aldridge et al. 2008, Lodeiros et al. 2019). Additionally, they can be vectors of parasites associated with low yield in shrimp production, producing nematosis (gregarines). A new species of the parasite (Apicomplexa, Porosporidae) 
has been identified, the gregarine Nematosis mytella. It was isolated and characterized from $M$. guyanensis (Azevedo \& Matos 1999) and has also been found in M. strigata (Padovan et al. 2003), representing a source of infestation towards shrimp.

The eradication of mussels from shrimp farms is practically impossible unless only bivalves are found on the farm, so it is more advisable to have control measures. However, these measures may vary by region, the type of shrimp farm, the production system, and the species of mussel, and they range from a simple change in pool management regimes through the establishment of meshes, the biological control, and even the use of chemicals and natural saponifying substances. However, chemical substances are a frequent practice, which could cause problems for the environment (Aldridge et al. 2008).

The present study demonstrates $M$. strigata presence in a shrimp farm in the southern Caribbean Sea, where its control must be developed to obtain greater performance in shrimp production. More knowledge of its life cycle, reproduction, growth rate, and behavior in the ecosystem should be obtained to implement control and eradication strategies. This study is the first record of the species for the Venezuelan Caribbean coast. However, an exhaustive study of genetic sequencing with more specimens from several locations in the Colombian-Venezuelan Caribbean region is necessary to know the genetic structure of native populations and the geographical origins.

\section{ACKNOWLEDGMENTS}

The collaboration of the evaluated shrimp farms is appreciated and that of Leandro Pantera Ramírez for his technical support in collecting and processing samples. We are grateful to Paul Valentich-Scott of the Santa Barbara Museum of Natural History, for the English and technical review of the text. We thank José Javier Alió Mingo for the final revision of the English in the manuscript. The CYTED program AquaCibus network 318RT0549 'Strengthening the aquaculture in Latin America: quality, competitiveness and sustainability' facilitated the interaction among the authors.

\section{REFERENCES}

Aldridge, D.C., Salazar, M., Serna, A. \& Cock, J. 2008. Density dependent effects of a new invasive false mussel, Mytilopsis trautwineana (Tryon, 1866), on shrimp, Litopenaeus vannamei (Boone, 1931), aquaculture in Colombia. Aquaculture, 281: 34-42.
Azevedo, C. \& Matos, E. 1999. Description of Nematopsis mytella n. sp. (Apicomplexa), parasite of the mussel Mytella guyanensis (Myteiidae) from the Amazon Estuary and description of its oocysts. European Journal of Protistology, 35: 427-433.

Baptiste, M.P., Castaño, N., Cárdenas, D., Gutiérrez, F., Gil, D.L. \& Lasso C.A. (Eds.). 2010. Análisis de riesgo y propuesta de categorización de especies introducidas para Colombia. Instituto de Investigación de Recursos Biológicos Alexander von Humboldt, Bogotá.

Bitter, R. \& Martínez, R. 2001. Inventario de los moluscos marinos en las costas del Estado Falcón, Venezuela. Acta Biologica Venezuelica, 21: 21-41.

Boltovskoy, D., Xu, M. \& Nakano, D. 2015. Impacts of Limnoperna fortunei on man-made structures and control strategies: general overview. In: Boltovskoy, D. (Ed). Limnoperna fortunei, invading nature. Springer, New York, pp. 375-394.

Boudreaux, M.L. \& Walters, L.J. 2006. Mytella charruana (Bivalvia: Mytilidae): a new, invasive bivalve in Mosquito Lagoon, Florida. Nautilus, 120: 34-36.

Calazans, S.H., Walters, L.J., Fernandes, F.C., Ferreira, C. \& Hoffman, E.A. 2017. Genetic structure provides insights into the geographic origins and temporal change in the invasive charru mussel (Sururu) in the southeastern United States. Plos One, 12: e0180619.

Capelo, J. \& Buitrago, J. 1998. Distribución geográfica de los moluscos marinos en el oriente de Venezuela. Memoria de la Fundación La Salle de Ciencias Naturales, 150: 109-160.

Coan, E.V. \& Valentich-Scott, P. 2012. Bivalve seashells of Tropical West America. Marine bivalve mollusks from Baja California to Northern Peru. Studies in Biodiversity 4, Santa Barbara Museum of Natural History, Santa Barbara.

Darrigran, G. \& Lagreca, M. 2005. Moluscos litorales del estuario del río de La Plata, Argentina. Pro Biota, Serie Técnica Didáctica 8. Universidad Nacional de La Plata, La Plata.

De la Hoz, M. 2013. Nuevos registros de Mytella charruana (Bivalvia: Mytilidae) en Colombia y algunas consideraciones sobre su ecología y estatus. Boletín del Centro de Investigaciones Biológicas, 47: 165-172.

Díaz, J.M. \& Puyana, M. 1994. Moluscos del Caribe colombiano. Un catálogo ilustrado. ColcienciasFundación Natura-Invemar, Bogotá.

Farías-Sánchez, J.A. 2006. Importance of the reproductive cycle and settlement pattern of the mussel Mytella strigata (Hanley, 1843) for the preventive maintenance of shrimp culture facilities in southern Sinaloa. In: Palacios, E., Lora, C., Ibarra, A.M., Maeda- 
Martínez, A.N. \& Racotta, I. (Eds.). Recent advances in reproduction, nutrition, and genetics of mollusks. Proceedings of the International Workshop Reproduction and Nutrition of Mollusks, La Paz, México, 6-9 November 2006. CIBNOR, Ciudad de Mexico.

Folmer, O., Black, M., Hoeh, W., Lutz, R. \& Vrijenhoek, R. 1994. DNA primers for amplification of mitochondrial cytochrome $\mathrm{c}$ oxidase subunit I from diverse metazoan invertebrates. Molecular Marine Biology and Biotechnology, 3: 294-299.

Galimany, E., Freeman, C., Lunt, J., Domingos, A., Sacks, P. \& Walters, L. 2017. Feeding competition between the native oyster Crassostrea virginica and the invasive mussel Mytella charruana. Marine Ecology Progress Series, 564: 57-66.

Gillis, N.K., Walters, L.J., Fernandes, F.C. \& Hoffman, E.A. 2009. Higher genetic diversity in introduced than in native populations of the mussel Mytella charruana: evidence of population admixture at introduction sites. Diversity and Distributions, 15: 784-795.

Gosling, E. 2003. Bivalve molluscs: biology, ecology, and culture. Fishing News Books, Oxford.

Jayachandran, P.R., Aneesh, B.P., Oliver, P.G., Philomina, J., Jima, M., Harikrishnan, K. \& BijoyNandan, S.B. 2019. First record of the alien invasive biofouling mussel Mytella strigata (Hanley, 1843) (Mollusca: Mytilidae) from Indian waters. BioInvasions Records, 8: 828-837.

Lim, J.Y., Tay, T.S., Lim, C.S., Lee, S.S.C., Teo, S.L.-M. \& Tan, K.S. 2018. Mytella strigata (Bivalvia: Mytilidae): an alien mussel recently introduced to Singapore and spreading rapidly. Molluscan Research, 38: 170-186.

Lodeiros, C., Marín, B. \& Prieto, A. 1999. Catálogo de moluscos marinos de las costas nororientales de Venezuela: clase Bivalvia. Asociación de Profesores de la Universidad de Oriente, Cumaná.

Lodeiros, C., González-Henríquez, N., Cuéllar-Anjel, J., Hernández-Reyes, D., Medina-Alcaraz, C. \& ReyMéndez, M. 2019. Invasion of the false mussel Mytilopsis leucophaeata (Conrad, 1831) in shrimp farms from Gulf of Venezuela: first report for the Caribbean Sea area. BioInvasions Records, 8: 838847.

Mackie, G. \& Claudi, R. 2010. Monitoring and control of macro fouling mollusks in fresh water systems. CRC Press, Taylor \& Francis Group, Boca Raton.

Mediodia, D., Santander, S., Ansco, N. \& Baylon, C. 2017. Shell morphology and anatomy of the Philippine charru mussel Mytella charruana (d'Orbigny 1842). Asian Fisheries Science, 30: 185-194.
MolluscaBase. 2021. MolluscaBase. Mytella strigata (Hanley, 1843). World Register of Marine Species. [http://marinespecies.org/aphia.php? $\mathrm{p}=$ taxdetails\&id= 1458663]. Reviewed: January 19, 2021.

Padovan, I., Tavares, L., Corral, L. \& Padovan, P. 2003. Fine structure of the oocyst of Nematopsis mytella (Apicomplexa, Porosporidae), a parasite of the mussel Mytella falcata and of the oyster Crassostrea rizophorae (Mollusca, Bivalvia) from the northeastern Atlantic coast of Brazil. Brazilian Journal of Morphological Sciences, 20: 141-145.

Paredes, C. \& Cardoso, F. 2008. Nuevos registros de bivalvos marinos para el Perú. Revista Peruana de Biología, 15: 11-14.

Puyana, M., Prato, J. \& Díaz, J.M. 2012. Mytella charruana (d'Orbigny) (Mollusca: Bivalvia: Mytilidae) en la Bahía de Cartagena, Colombia. Boletín de Investigaciones Marinas y Costeras, 40: 213-217.

Quirós, J.A. \& Arias, J.R. 2013. Taxocenosis de moluscos y crustáceos en raíces de Rhizophora mangle (Rhizophoraceae) en la Bahía de Cispatá, Córdoba, Colombia. Acta Biológica Colombiana, 18: 329-340.

Rice, M.A., Rawson, P.D., Salinas, A.D. \& Rosario, W.R. 2016. Identification and salinity tolerance of the Western Hemisphere mussel Mytella charruana (d'Orbigny, 1842) in the Philippines. Journal of Shellfish Research, 35: 865-873.

Rios, E.C. 1994. Seashells of Brazil. Fundacão Universidade do Rio Grande, Rio Grande.

Ruesink, J.L., Lenihan, H.S., Trimble, A.C., Heiman, K.W., Micheli, F., Byers, J.E. \& Kay, M.C. 2005. Introduction of non-native oysters: ecosystem effects and restoration implications. Annual Review of Ecology, Evolution, and Systematics, 36: 643-689.

Sanpanich, K. \& Wells, F.E. 2019. Mytella strigata (Hanley, 1843) emerging as an invasive marine threat in Southeast Asia. BioInvasions Records, 8: 343-356.

Soot-Ryen, T. 1955. A report on the family Mytilidae (Pelecypoda). Allan Hancock Pacific Expeditions, 20: $1-175$.

Spalding, M.D., Fox, H.E., Allen, G.R., Davidson, N., Ferdana, Z.A., Finlayson, M.A., et al. 2007. Marine ecoregions of the world: a bioregionalization of coastal and shelf areas. BioScience, 57: 573-583.

Spinuzzi, S., Schneider, K., Walters, L., Yuan, W. \& Hoffman, E. 2013. Tracking the distribution of nonnative marine invertebrates (Mytella charruana, Perna viridis, and Megabalanus coccopoma) along the southeastern USA. Marine Biodiversity Records, 6: e55.

Stenyakina, A., Walters, L.J., Hoffman, E.A. \& Calestani, C. 2010. Food availability and sex reversal in Mytella 
charruana, an introduced bivalve in the southeast United States. Molecular Reproduction and Development, 77: 222-230.

Strayer, D.L. 1999. Effects of alien species on freshwater mollusks in North America. Journal of the North American Benthological Society, 18: 74-98.

Received: 22 August 2020; Accepted: 9 May 2021
Vallejo, B.J., Conejar-Espedido, J., Manubag, L., Artiaga, K.C.C., Damatac II, A.M., Imperial, I.C.V.J., et al. 2017. First record of the charru mussel Mytella charruana d'Orbygny, 1846 (Bivalvia: Mytilidae) from Manila Bay, Luzon, Philippines. BioInvasions Records, 6: 49-55.

Wells, F.E. 2017. If the Asian green mussel, Perna viridis (Linnaeus, 1758), poses the greatest invasive marine species threat to Australia, why has it not invaded? Molluscan Research, 37: 167-174. 